\title{
Effects of COREXIT ${ }^{\circledR}$ EC9500A on bacteria from a beach oiled by the Deepwater Horizon spill
}

\author{
Leila J. Hamdan ${ }^{1, *}$, Preston A. Fulmer ${ }^{2}$ \\ ${ }^{1}$ Marine Biogeochemistry Section, Code 6114, U.S. Naval Research Laboratory, Overlook Ave. SW, Washington, \\ DC 20375, USA \\ ${ }^{2}$ Bioenergy and Biofabrication Section, Code 6115, U.S. Naval Research Laboratory, Overlook Ave. SW, Washington, \\ DC 20375, USA
}

ABSTRACT: Hydrocarbon-degrading bacteria are important for controlling the fate of natural and anthropogenic hydrocarbons in the marine environment. In the wake of the Deepwater Horizon spill in the Gulf of Mexico, microbial communities will be important for the natural attenuation of the effects of the spill. The chemical dispersant COREXIT ${ }^{\circledR}$ EC9500A was widely deployed during the response to the Deepwater Horizon incident. Although toxicity tests confirm that COREXIT $^{\circledR}$ EC9500A does not pose a significant threat to invertebrate and adult fish populations, there is limited information on its effect on microbial communities. We determined the composition of the microbial community in oil that had been freshly deposited on a beach in Louisiana, USA, as a result of the Deepwater Horizon spill. The metabolic activity and viability in cultures obtained from oil samples were determined in the absence and presence of COREXIT ${ }^{\circledR}$ EC9500A at concentrations ranging from 0.001 to $100 \mathrm{mg} \mathrm{ml}^{-1}$. In length heterogeneity PCR (LH-PCR) fingerprints of oil samples, the most abundant isolates were those of Vibrio, followed by hydrocarbon-degrading isolates affiliated with Acinetobacter and Marinobacter. We observed significant reductions in production and viability of Acinetobacter and Marinobacter in the presence of the dispersant compared to controls. Of the organisms examined, Marinobacter appears to be the most sensitive to the dispersant, with nearly $100 \%$ reduction in viability and production as a result of exposure to concentrations of the dispersant likely to be encountered during the response to the spill (1 to $10 \mathrm{mg}$ $\mathrm{ml}^{-1}$ ). Significantly, at the same concentration of dispersant, the non-hydrocarbon-degrading Vibrio isolates proliferated. These data suggest that hydrocarbon-degrading bacteria are inhibited by chemical dispersants, and that the use of dispersants has the potential to diminish the capacity of the environment to bioremediate spills.

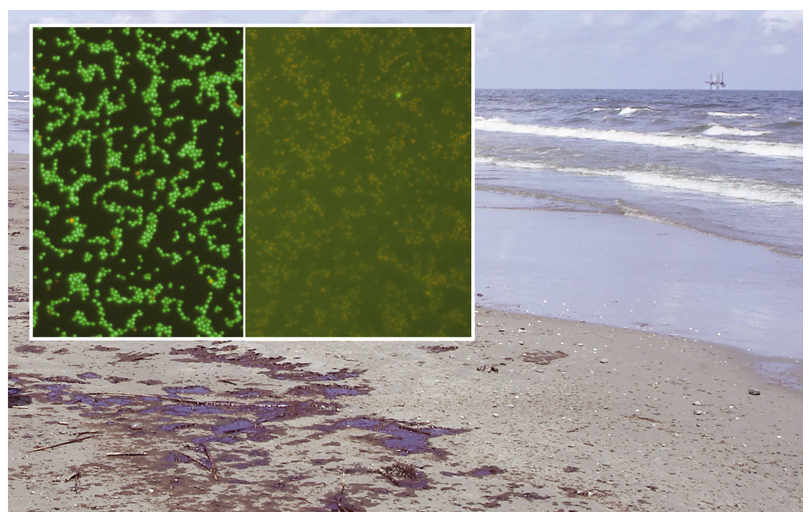

Oil from the Deepwater Horizon spill washing ashore on Elmer's Island, Louisiana, USA, in May 2010. Inset: viability assay for the hydrocarbon-degrading bacterium Acinetobacter venetianus before (left) and after (right) exposure to COREXIT, revealing inhibition by the chemical dispersant.

Photo: Warren Wood; inset: Leila J. Hamdan

KEY WORDS: Deepwater Horizon - Gulf of Mexico • Dispersant - Hydrocarbon degraders ' Vibrio . COREXIT · Toxicity

Resale or republication not permitted without written consent of the publisher

\section{INTRODUCTION}

The mobile offshore drilling unit 'Deepwater Horizon' experienced an explosion on April 20, 2010, and sank 2 d later (Coastal Response Research Center 2010). As a result of the explosion, and failure of a blowout preventer on the sea floor, crude oil began leaking from a broken riser pipe into the Gulf of Mexico at an estimated rate of 19000 to 70000 barrels ( 3000 to $11000 \mathrm{~m}^{3}$ ) of oil d $\mathrm{d}^{-1}$ (Labson et al. 2010). This resulted in the largest oil spill in the coastal waters of the USA. 
Natural seepage of hydrocarbons is an important source of carbon for benthic environments in the Gulf of Mexico and is a structuring factor for benthic and near-bottom microbial communities (National Research Council Committee on Oil in the Sea 2003). In marine environments, bacteria are the predominant degraders of hydrocarbons (Leahy \& Colwell 1990) and thus are of great importance in controlling the fate of natural and anthropogenic seepage. In such environments, microbial communities contain members predisposed to hydrocarbon metabolism (Aharon \& Fu 2000, Lanoil et al. 2001). Microbial assemblages associated with hydrocarbon seeps are well characterized in Gulf of Mexico sediments (Hollaway et al. 1980, Aharon \& Fu 2000, Lanoil et al. 2001, Mills et al. 2003, Joye et al. 2004, Reed et al. 2006, Lloyd et al. 2010, Orcutt et al. 2010). The impact of natural seepage on water-column communities has been relatively less studied, although microorganisms with the ability to degrade hydrocarbons are ubiquitously distributed in waters along continental shelves (Venkateswaran et al. 1991). Because large-scale impacts of hydrocarbons on Gulf of Mexico beaches are rare, little is known about the microbial communities which live in proximity to beached oil.

In the USA, the Environmental Protection Agency (EPA) maintains a list of chemicals and spill-mitigating devices which may be deployed during an oil spill in coastal waters of the USA; this is a part of the National Contingency Plan (NCP) (US EPA 2010b). NCPapproved dispersants are applied to break up masses of oil and reduce the formation of surface slicks. This is done to reduce the incidence of oil coating on populations of birds, mammals and invertebrates. In the wake of the Deepwater Horizon spill, dispersants were deployed widely in surface and sub-surface waters (Coastal Response Research Center 2010). As of early June 2010, more than 990000 gallons $\left(\sim 3700 \mathrm{~m}^{3}\right)$ of dispersant were used in the response. The most commonly used dispersant was COREXIT ${ }^{\circledR}$ EC9500A (Nalco). There is limited knowledge regarding the communities that metabolize oil in the water column and on coastal beaches. Even less is known about the impact of dispersants in general-and specifically COREXIT ${ }^{\circledR}$ EC9500A-on hydrocarbon-degrading microbial communities in the Gulf of Mexico.

Dispersants have been suggested as a means to improve microbial biodegradation of oil contamination in the water column by forming small oil droplets with high surface-to-volume ratios which increase their lability to microplankton (Brakstad 2008). However, this same process is likely to increase the concentration and lability of spill-related toxic compounds in the water column, which may, in turn, affect the microbial hydrocarbon-degrading community (Zahed et al.
2010). Furthermore, the dispersants themselves may impact hydrocarbon-degrading microorganisms.

Thus, the goal of this study was to understand the impact of COREXIT ${ }^{\circledR}$ EC9500A (henceforth referred to as 'COREXIT') on bacterial viability and metabolic function in oiled beach samples from the area affected by the Deepwater Horizon spill. These samples may be ideal candidates for such analysis because microbial communities have been acclimatized to conditions of high contamination by hydrocarbons, environmental weathering and possibly in situ exposure to dispersants. Future studies of the impact of dispersants on microbial communities should also include analysis of 'pristine' environmental communities. Studies of both exposed and pristine communities will be of importance in understanding the long-term affects of the spill and the use of chemical dispersants in aquatic environments. Previous studies have documented clear evidence of the deleterious effect of the dispersant on wildlife and microbial communities (Lindstrom \& Braddock 2002, Couillard et al. 2005, Jung et al. 2009). Due to the unknown effects of the large-scale use of dispersant on microbial communities in affected areas, more study is warranted on the effects of the widespread application of dispersant.

\section{MATERIALS AND METHODS}

Sample collection and handling. Beached oil samples were collected on May 22, 2010, from the south end of the Elmer's Island Wildlife Refuge (EIWR), Louisiana, USA, on the seaward facing shore. Personal accounts from EIWR staff indicate that accumulations of oil reached the beach mid-day on the previous day. During sampling, small brown pea-sized floating droplets of oil were observed in the water within $0.5 \mathrm{~m}$ of the high-water mark, and pools of thick oil were deposited at the high-water mark along the beach. Oil on the beach appeared in several different forms, related to how long it had been deposited (EIWR staff personal account). Oil that had been on the beach longer than $24 \mathrm{~h}$ had soaked into the sand. Fresher oil rested on the surface of the sand. Freshly deposited oil was collected in cellulose acetate butyrate core liners, capped at both ends, and later sub-sampled into sterile $50 \mathrm{ml}$ polyethylene tubes. Samples were maintained at ambient temperature during transport from the field ( $24 \mathrm{~h})$ and subsequently held in the dark on ice during shipping to the laboratory $(48 \mathrm{~h})$. The total time between sample collection and analysis was $\sim 72 \mathrm{~h}$. Because of these hold times, alterations in the structure of the microbial community may have occurred; this may have resulted in the enhancement of some phylotypes, masking of the appearance of phylotypes accounting for less than $1 \%$ 
of the population in LH-PCR and culture analysis, or loss of cultivability of others.

Bacterial abundance. A modification of the method of Hobbie et al. (1977), described in Hamdan \& Jonas (2006), was used to determine bacterial abundance. Oil and oil-water (liquid surrounding the oil) was diluted 1:100 with buffered sterile seawater, stained with $0.1 \%$, acridine orange, collected on black polycarbonate filters of pore size $0.2 \mu \mathrm{m}$ (Osmonics) and observed at $1000 \times$ magnification.

Cultivation conditions. Marine agar (MA) (Difco) was used as a complete medium for bacterial growth. Bushnell-Haas (BH) agar (Difco) supplemented with $1 \% \mathrm{w} / \mathrm{v}$ hexadecane (Fisher Scientific) was used as a selective medium to isolate hydrocarbon degraders. All media were prepared according to the manufacturer's specifications. Culturable bacteria were assessed using standard microbial culture techniques. Approximately $10 \mu \mathrm{l}$ of oil or oil-water was plated on MA and BH using a quadrant streak method. Plates were incubated at $30^{\circ} \mathrm{C}$. Colonies were isolated based on morphology and re-plated to produce pure cultures.

Isolation of genomic DNA and 16S rDNA sequencing. To identify members of the microbial community, individual colonies from MA and $\mathrm{BH}$ plates were added to $5 \mathrm{ml}$ of marine broth (MB) and incubated for $18 \mathrm{~h}$ at $30^{\circ} \mathrm{C}$. Genomic DNA was isolated by alkaline lysis. For this, $2 \mathrm{ml}$ of $\mathrm{MB}$ culture was centrifuged at $4000 \times g$. The medium was removed and cells were resuspended in $1 \mathrm{ml}$ sterile phosphate-buffered saline (PBS). Cells were pelleted again at $4000 \times g$ and resuspended in $50 \mathrm{mM}$ Tris- $\mathrm{Cl}$ (pH 8.0), $10 \mathrm{mM}$ EDTA, and $1 \mathrm{mg} \mathrm{l}^{-1}\left(1 \mu \mathrm{g} \mathrm{ml}^{-1}\right)$ RNase A. Cells were then lysed in a buffer containing $200 \mathrm{mM} \mathrm{NaOH}$ and $1 \%$ sodium dodecyl sulfate (SDS), and the solution was neutralized with $3.0 \mathrm{M}$ potassium acetate. Lysates were centrifuged at $15000 \times g$ to remove cell debris, and supernatants were collected. DNA was precipitated with isopropyl alcohol and centrifuged at $15000 \times g$, washed with ethanol, and dried at room temperature prior to resuspension in $10 \mathrm{mM}$ Tris- $\mathrm{Cl}(\mathrm{pH}$ 8.5). DNA $(1 \mu \mathrm{g})$ was used as a template for a PCR as follows: 1 U Failsafe Enzyme mix (Epicentre Biotechnologies), $2 \times$ Failsafe Premix E, 2 mM 27F 16s rDNA universal bacterial primer (5'-AGA GTT TGA TCC TGG CTC AG-3'), and 2 mM 1492R 16s rDNA universal bacterial primer (5'ACG GCT AGC TTG TTA CGA CTT-3'). Reactions were run as follows: $94^{\circ} \mathrm{C}$ for $5 \mathrm{~min}^{2} 20$ cycles of $94^{\circ} \mathrm{C}$ for $30 \mathrm{~s}, 50^{\circ} \mathrm{C}$ for $30 \mathrm{~s}$, and $72^{\circ} \mathrm{C}$ for $90 \mathrm{~s} ; 72^{\circ} \mathrm{C}$ for $7 \mathrm{~min}$. PCR product was visualized on a $1 \%$ agarose gel containing ethidium bromide. Bands of $\sim 1500$ bp size were excised and purified using a gel purification kit (Qiagen). Excised PCR products were sequenced by Genewiz and checked for homology to known sequences in GenBank using the BLASTn algorithm.
Length heterogeneity polymerase chain reaction (LH-PCR). Genomic DNA was extracted from 500 mg of oil and oil-water mixtures using the Bio 101 FastDNA ${ }^{\circledR}$ SPIN kit for soil. DNA was quantitated on a $1 \%$ agarose gel with ethidium bromide and diluted with DEPCtreated water such that $\sim 10$ ng of DNA was used as template for LH-PCR. Environmental samples (oil and oilwater) and isolates were analyzed by LH-PCR.

Hamdan et al. (2008) provides a detailed description of LH-PCR. Briefly, amplification of variable regions $\mathrm{V} 1$ and V2 of the small subunit rRNA gene was performed using the primers 6-FAM-27F (5'-6-FAM-AGA GTT TGA TCM TGG CTC AG-3') and 355R (5'-GCTGCC TCC CGT AGG AGT-3'). Controls accompanied reactions to determine PCR efficiency and calibrate peak intensity. PCR mixtures consisted of $1 \times$ Gold buffer, $2.5 \mathrm{mM} \mathrm{MgCl} 2,0.2 \mathrm{mM}$ dNTPs, $0.5 \mathrm{U}$ AmpliTaq Gold, $0.5 \mu \mathrm{M}$ primers, $0.01 \% \mathrm{BSA}$, and diethylpyrocarbonate (DEPC)-treated water. PCR was performed on a GeneAmp System 9700 (Applied Biosystems) with the following program: 20 to 30 cycles of $95^{\circ} \mathrm{C}(30 \mathrm{~s}), 48^{\circ} \mathrm{C}$ $(30 \mathrm{~s}), 72^{\circ} \mathrm{C}(2 \mathrm{~min}$ plus $5 \mathrm{~s}$ per cycle) and final extension at $72^{\circ} \mathrm{C}(30 \mathrm{~min})$. PCR product was diluted, mixed with ILS-600 (Promega) and HiDi formamide and loaded on an ABI 3130xl Analyzer (Applied Biosystems). LH-PCR was performed on the isolates, and the resulting amplicons were virtually aligned with LHPCR amplicons from the environmental samples so that the latter could be attributed to one or more isolates. In this manner, the contribution of isolates to the environmental community was determined. LH-PCR was also performed using universal archaeal primers. No product was obtained with archaeal primers $1 \mathrm{HKF}$ and 589R (see Litchfield et al. 2005 for details); thus, we conclude that most of the environmental community belongs to the bacterial domain.

Bacterial viability. The effect of COREXIT (Nalco, batch \# SLOE 1184) on bacterial growth was determined using a BacLight ${ }^{\mathrm{TM}}$ (Invitrogen) Live/Dead Bacterial Viability assay. COREXIT is a mixture of light petroleum distillates (10 to $30 \%$ ), propylene glycol (1 to $5 \%$ ) butanedioic acid, 2-sulfo-1,4-bis(2-ethylhexyl) ester, sodium salt (10 to $30 \%)$, in addition to unspecified amounts of propanol and sorbitan (www.nalco.com, www.epa.gov). Assays were conducted according to the manufacturer's instructions, including standardization curves for each strain. To determine the toxicity of COREXIT for isolates, 10-fold serial dilutions of COREXIT, ranging from 1:10 to 1:100 000, in MB were added to wells of a 96-well microtitre plate. Approximately $10^{6}$ colony-forming units (cfu) from a mid-log phase culture of each isolate (in triplicate) were added to the wells and incubated at $30^{\circ} \mathrm{C}$ for $18 \mathrm{~h}$. Cells were pelleted at $3000 \times g$ and resuspended in sterile $0.85 \% \mathrm{NaCl}_{\text {, }}$ followed by staining using the BacLight ${ }^{\mathrm{TM}}$ kit. Bacterial 
viability was determined using a FLx800 (BioTek) microplate reader.

To determine the effect of COREXIT on hydrocarbon utilization by isolates with known hydrocarbondegrading capabilities, we used Bushnell-Haas (BH) agar supplemented with $1 \% \mathrm{w} / \mathrm{v}$ hexadecane. COREXIT was added to the medium-hexadecane mix at ratios of 1:10, 1:25 and 1:50 COREXIT:hexadecane. Cultures were assayed as above.

Heterotrophic bacterial production. Production was measured as leucine incorporation (Smith \& Azam 1992). Briefly, $0.50 \mathrm{ml}$ aliquots of oil, oil-water and $\mathrm{MB}$ cultures were added to microcentrifuge tubes (3 experimental and 1 abiotic control) that contained $\left[{ }^{3} \mathrm{H}-4,5\right]-$ L-leucine $\left(154 \mathrm{mCi} \mathrm{mmol}^{-1}\right)$ and incubated for $1 \mathrm{~h}$ at $25^{\circ} \mathrm{C}$. Incubations were terminated by the addition of $100 \%$ trichloroacetic acid (TCA). Samples were centrifuged to pellet cells and washed with 5\% TCA and ethanol to remove unincorporated radiolabel. Radioactivity was determined on a Beckman-Coulter LS6500 liquid scintillation counter. MB cultures of isolates containing no COREXIT and containing 1 of 2 dilutions of COREXIT (final conc. $\sim 1$ and $10 \mathrm{mg} \mathrm{ml}^{-1}$ in MB) were used. These were held for $48 \mathrm{~h}$ and sampled at $t=0,6$, 12,24 and $48 \mathrm{~h}$.

\section{RESULTS}

Cell abundance in the oil-water fraction of the sample was $2.9 \times 10^{11}$ cells $1^{-1}$. Measurements of cell abundance on the oil sample were not possible even when dispersed, as the sample matrix clogged filters, making accurate measurements impossible. Heterotrophic secondary production in the oil-water was $2.7 \times 10^{9}$ cells $^{-1} \mathrm{~d}^{-1}$, indicating a high standing stock of cells in the stationary phase of growth.

Eight isolates were identified from the environmental samples (oil and oil-water) (Table 1). Most isolates were members of the class Gammaproteobacteria. With the exception of the isolates related to Exiguobacterium arabatum and Acinetobacter venetianus, all matched most closely (>96\%) with environmental clones obtained from marine or coastal waters. Among the isolates were 3 known hydrocarbon degraders (Table 1). A total of 15 LH-PCR amplicons were observed in the samples (Table 1). The Simpson's Index $(D)$ was used to estimate bacterial diversity. Diversity was relatively low in the oil and oil-water samples ( 0.15 and 0.20 , respectively), and 4 amplicons accounted for the majority of the LH-PCR peak area. The 4 peaks that accounted for the majority of peak abundance corresponded with 3 isolates and 1 unidentified amplicon (Table 1). Vibrio sp. was highly abundant in both samples and, alone, accounted for $\geq 31 \%$ of the peak area in both samples.

Experiments to assess the acute toxicity of COREXIT for environmental isolates are summarized in Fig. 1. The addition of COREXIT resulted in varying levels of reduction in cell viability, and an increase in cell numbers in some cases. A reduction in live cells was seen for all isolates at all concentrations tested with the

Table 1. Summary of isolates obtained from oil and oil-water samples and LH-PCR (length heterogeneity PCR) analysis of samples and isolates

\begin{tabular}{|c|c|c|c|c|c|c|c|}
\hline Isolate & Phylogenetic group & $\begin{array}{c}\text { Nearest } \\
\text { relative } \\
\text { (GenBank } \\
\text { Accession no.) }\end{array}$ & $\begin{array}{l}\text { Alignment } \\
(\%)\end{array}$ & $\begin{array}{l}\text { Amplicon } \\
\text { length } \\
\text { (bp) }\end{array}$ & $\begin{array}{l}\text { Hydrocarbon } \\
\text { degrader }\end{array}$ & $\begin{array}{c}\text { Cumulative } \\
\text { abundance } \\
\text { Oil-water }\end{array}$ & $\begin{array}{l}\text { peak } \\
(\%) \\
\text { Oil }\end{array}$ \\
\hline Acinetobacter venetianus & Gammaproteobacteria & AM909651 & 99 & 338 & Yes & 4 & 4 \\
\hline Exiguobacterium arabatum & Bacillales & FM203124 & 99 & 359 & No & $<1$ & 0 \\
\hline $\begin{array}{l}\text { Marinobacter } \\
\text { hydrocarbonoclasticus }\end{array}$ & Gammaproteobacteria & GQ901055 & 100 & 341 & Yes & 12 & 12 \\
\hline Pseudidiomarina sp. & Gammaproteobacteria & EF212001 & 96 & 357 & No & $<1$ & $<1$ \\
\hline Pseudoalteromonas sp. & Gammaproteobacteria & GQ245921 & 99 & 344 & No & 17 & 13 \\
\hline $\begin{array}{l}\text { Pseudomonas } \\
\text { pseudoalcaligenes }\end{array}$ & Gammaproteobacteria & EU440977 & 99 & 336 & Yes & $<1$ & $<1$ \\
\hline Shewanella algae & Gammaproteobacteria & DQ386137 & 98 & 346 & No & 5 & 10 \\
\hline Vibrio sp. & Gammaproteobacteria & EU834012 & 99 & $353 / 354$ & Yes & 31 & 32 \\
\hline Unmatched amplicon & & & & 302 & Unknown & 0 & 2 \\
\hline Unmatched amplicon & & & & 310 & Unknown & 5 & 3 \\
\hline Unmatched amplicon & & & & 312 & Unknown & 9 & 16 \\
\hline Unmatched amplicon & & & & 320 & Unknown & 1 & 0 \\
\hline Unmatched amplicon & & & & 322 & Unknown & 10 & 3 \\
\hline Unmatched amplicon & & & & 327 & Unknown & 2 & 2 \\
\hline Unmatched amplicon & & & & 329 & Unknown & 1 & 3 \\
\hline
\end{tabular}




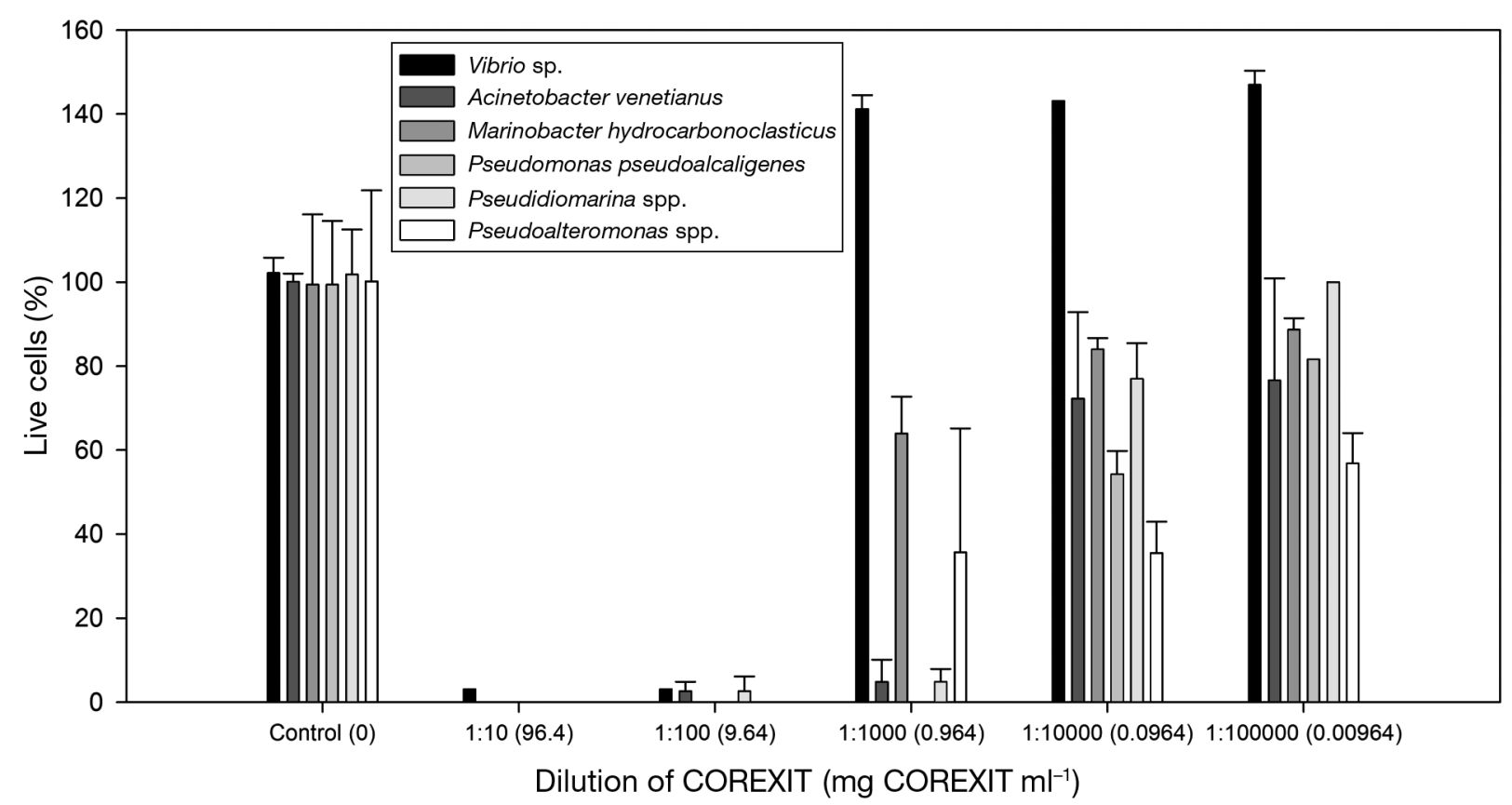

Fig. 1. Toxicity of COREXIT ${ }^{\circledR}$ EC9500A to isolated strains. Dispersant dilutions are 1:10 to 1:100 000 w/v. Values in parentheses are the concentration of dispersant in each treatment. Percentages of live cells in dispersant-amended cultures are relative to the controls. Error bars are $\pm 1 \mathrm{SD}$

exception of Vibrio sp. Dilutions of COREXIT of 1:10 and $1: 100 \mathrm{w} / \mathrm{v}$ in Marine broth resulted in near total cell death for all isolates $(\geq 99 \%)$. However, at the 1:1000 dilution, corresponding to the addition of $0.964 \mathrm{mg} \mathrm{ml}^{-1}$ COREXIT, there was an increase in live cells of Vibrio sp. compared to the control, and a decrease in live cells (40 to $90 \%$ ) in all other cultures (relative to controls).

To address the effects of COREXIT on hydrocarbon degraders, dilutions of COREXIT were added to minimal medium supplemented with hexadecane as a carbon source. COREXIT was added at the concentrations suggested by the Environmental Protection Agency (EPA), i.e. ratios of 1:10, 1:25 and 1:50 COREXIT:hexadecane (US EPA 1995); the results are summarized in Fig. 2. Such ratios of COREXIT to hydrocarbons may have been encountered during surface and deepwater application in the response to the spill, but dispersant concentrations may have been significantly lower within the water column and on affected beaches. Thus, we suggest that these concentrations represent the maximum encountered in the environment. As before, the addition of COREXIT was toxic to all hydrocarbon degraders in a dose-dependent manner.

A second experiment was conducted to determine the impact of COREXIT on heterotrophic secondary production. The results of this experiment are summarized in Fig. 3. At $t=0 \mathrm{~h}$ in all 3 cultures, there were statistically significant differences between treatments and controls. In the Acinetobacter venetianus and Marinobacter hydrocarbonoclasticus cultures, addition of the dispersant moderately stimulated production compared to the controls. In the Vibrio sp. culture, a

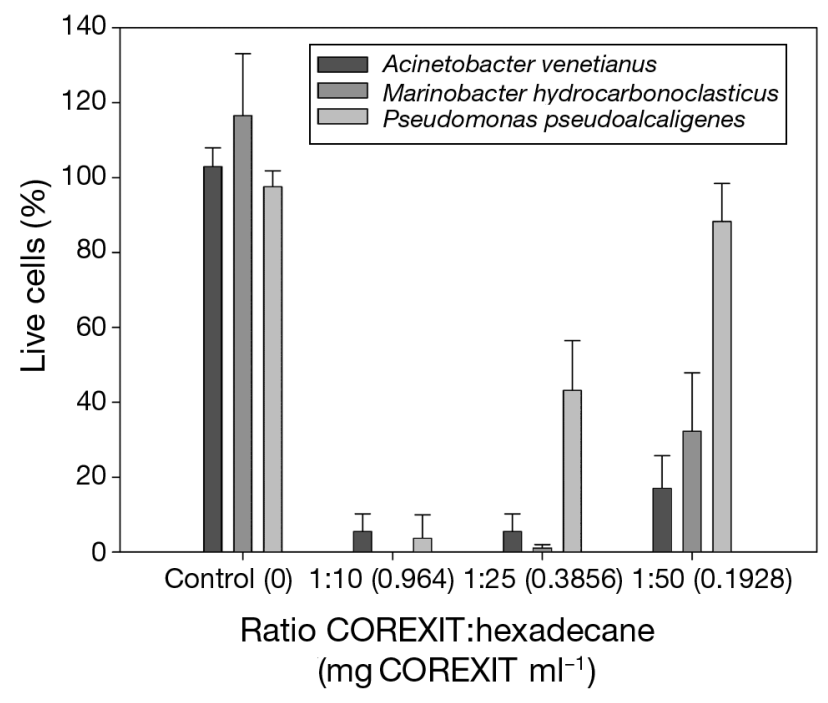

Fig. 2. Toxicity of COREXIT $^{\circledR}$ EC9500A to hydrocarbon degraders when present at concentrations suggested by the Environmental Protection Agency (EPA). Dispersant dilutions are 1:10, 1:25 and 1:50 ratios of COREXIT to hexadecane. Values in parentheses are the concentration of dispersant in each treatment. Error bars are $\pm 1 \mathrm{SD}$ 

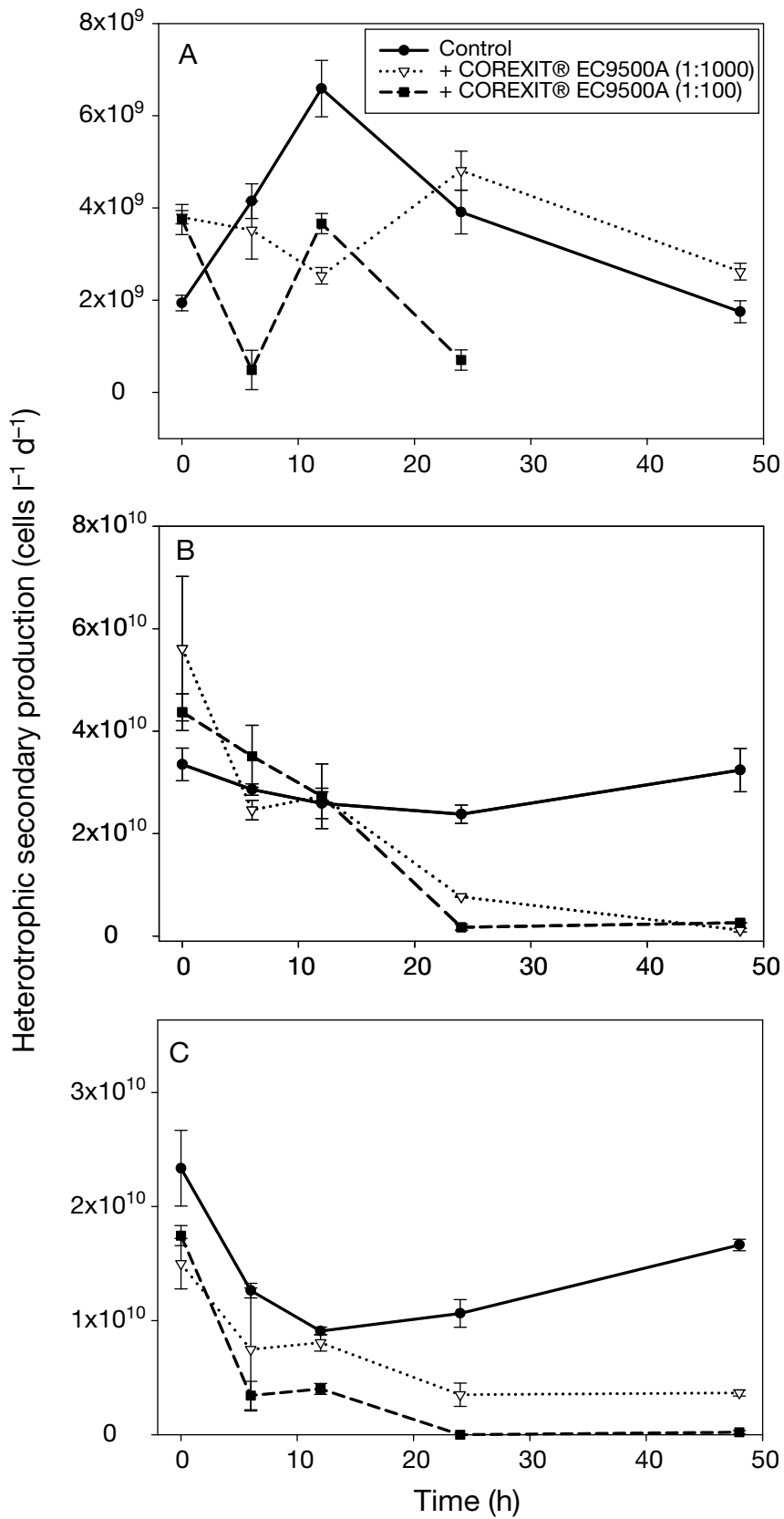

Fig. 3. Time course experiment tracking heterotrophic bacterial production in 3 cultures: (A) Acinetobacter venetianus, (B) Marinobacter hydrocarbonoclasticus, and (C) Vibrio sp. No sample for $t=48 \mathrm{~h}$ for $A$. venetianus + dispersant at 1:100 was available due to evaporative loss. Error bars are $\pm 1 \mathrm{SD}$

moderate decline in production was observed at $t=$ $0 \mathrm{~h}$. At $t=12 \mathrm{~h}$ COREXIT clearly inhibited $A$. venetianus secondary production compared to the controls; such inhibition remained significant in the highest dilution of COREXIT until $t=24 \mathrm{~h}$. Interestingly, in the 1:1000 dispersant dilution, production of $A$. venetianus rebounded to the level of the control at $t=24 \mathrm{~h}$ and exceeded the control at $t=48 \mathrm{~h}$. Production by $M$. hydrocarbonoclasticus remained similar in all treatments until $t=12 \mathrm{~h}$. After $t=12 \mathrm{~h}$, a biofilm appeared slightly above the medium in treatments containing COREXIT, and production declined significantly, while in the control it remained consistent for the duration of the experiment. In Vibrio sp., production in all treatments declined during the first $12 \mathrm{~h}$ of the experiment. After $t=12 \mathrm{~h}, \mathrm{a}$ concentration-dependent decline in production was observed in the dispersant treatments while the control rebounded. A biofilm was also observed in COREXIT-amended Vibrio sp. tubes after $t=12 \mathrm{~h}$.

\section{DISCUSSION}

LH-PCR revealed a relatively low-diversity population. This is not surprising given the nature of the samples and that others document low diversity in oil-rich environments (Orcutt et al. 2010). Experiments to determine microbial responses to oil contamination using pristine marine sediments demonstrate rapid increases in the abundance of hydrocarbon degraders (Brakstad 2008). Thus, we hypothesized that the environmental samples would be enriched in microorganisms capable of hydrocarbon degradation.

Over 80 bacterial genera have been confirmed to degrade hydrocarbons (Head et al. 2006, Brakstad 2008). The most commonly observed hydrocarbon degraders in aquatic environments belong to the Gammaproteobacteria and include the genera Pseudomonas, Acinetobacter, Marinobacter and Alcanivorax (Atlas 1981, Venkateswaran et al. 1991, Head et al. 2006). Fewer reports indicate that Vibrio spp. are involved in hydrocarbon degradation (Atlas 1981, Venkateswaran et al. 1991).

Virtual alignment of LH-PCR amplicons with isolate amplicons reveals that a total of $17 \%$ of peak abundance was associated with 3 known hydrocarbon degraders (Table 1). The most abundant of these was Marinobacter hydrocarbonoclasticus. The M. hydrocarbonoclasticus isolate exhibited $100 \%$ homology with an isolate obtained from coral tissue, infected with Black Band Disease, obtained proximate to the Gulf of Mexico (Richardson et al. 2009). M. hydrocarbonoclasticus can degrade a variety of aliphatic and aromatic hydrocarbons and produce a nondialyzable bioemulsifier when grown on hydrocarbons (Gauthier et al. 1992). One of the main features that distinguish the genus Marinobacter from closely related genera is the ability of these bacteria to tolerate high levels of salt and to grow at temperatures up to $45^{\circ} \mathrm{C}$. These factors suggest that the location in which the sample was found-and high ambient temperatures on the beach at the time of collection - may have selected for this isolate. 
The second most abundant hydrocarbon degrader in the environmental fingerprint was related $99 \%$ to Acinetobacter venetianus. Other studies have demonstrated that $A$. venetianus proliferates in oil-degrading consortia and is capable of metabolizing complex marine hydrocarbon mixtures (Vaneechoutte et al. 2009). Some strains of A. venetianus produce bioemulsifiers to aid in hydrocarbon metabolism. Pseudomonas pseudoalcaligenes, a confirmed naphthalene degrader (Garcia-Valdes et al. 1988), was detected in the LHPCR profile, although its amplicon accounted for less than $1 \%$ of peak abundance.

Vibrio sp. accounted for the majority of LH-PCR peak abundance. The Vibrio isolate was $99 \%$ related to 4 Vibrio phylotypes: Vibrio natriegens, alginolyticus, fluvialis and the pathogenic vulnificus. All GenBank entries which matched the Vibrio sp. isolate are capable of rapid growth, with generation times of less than 10 min (Aiyar et al. 2002). Each is capable of forming biofilms, which may explain the biofilm observed in the production tubes. V. fluvialis and $V$. natriegens have been identified in hydrocarbon-degrading communities in experimental seawater mesocosms (Venkateswaran et al. 1991); however, their role as hydrocarbon degraders is not well recognized. In experimental studies, $V$. natriegens was capable of metabolizing insoluble surfactants at air-water interfaces (Salter et al. 2009). This ability to metabolize surfactants may explain why the Vibrio sp. isolate showed greater viability in the presence of COREXIT compared to other phylotypes in this study.

At some concentrations, all isolates were susceptible to impairment as a result of exposure to COREXIT. The addition of dispersant, at all concentrations, resulted in a significant reduction in the live:dead cell ratio in all isolates tested-with the exception of Vibrio sp., which, of the organisms examined, appear to be the most tolerant to COREXIT (Figs. 1 \& 2).

Because of the importance of microorganisms to the natural attenuation of hydrocarbons, toxicity tests were focused on hydrocarbon-degrading isolates. COREXIT at concentrations $<1 \mathrm{mg} \mathrm{ml}^{-1}$ was capable of killing at least $60 \%$ of cells in cultures of the 2 most abundant hydrocarbon-degrading isolates observed in the LH-PCR profile (Fig. 2). This is a significant finding given that the $1: 50$ dilution, $\sim 0.2 \mathrm{mg} \mathrm{ml}^{-1}$, is within the concentration range for COREXIT ${ }^{\circledR}$ EC9500A classified as 'practically non-toxic' to the standard toxicity test organism Menidia beryllina (US EPA 2010a). The result for $M$. beryllina was included in a recent Environmental Protection Agency (EPA) report identifying the environmental hazards associated with the use of National Contingency Plan (NCP)-approved dispersants during the Deepwater Horizon response. The results of the current study demonstrate that, at concentrations which do not present a significant hazard to some adult test organisms, dispersants may be highly toxic to communities directly involved in natural hydrocarbon bioremediation.

In the second live:dead experiment, in which hexadecane was added to growth media (Fig. 2), we confirm that cell death results from the application of the dispersant, not from limitation of hydrocarbons. Interestingly, in the presence of hexadecane, Pseudomonas pseudoalcaligenes exhibited the greatest resistance to COREXIT toxicity, suggesting that the presence of hydrocarbons may reduce the impact of COREXIT on some populations.

In microcosm studies conducted on Alaskan North Slope crude oil treated with COREXIT ${ }^{\circledR}$ EC9500A, the dispersant did increase the surface area of crude oil droplets and enhanced microbial droplet colonization (Lindstrom \& Braddock 2002). However, the dispersants resulted in a negligible increase in biodegradation of oil when compared to non-dispersed oil. COREXIT can be a highly labile substrate for microbial growth and metabolism (Zahed et al. 2010), and increases in carbon mineralization in oil samples may be attributed to mineralization of the chemical dispersant alone (Lindstrom \& Braddock 2002, Brakstad 2008). This may explain the results observed for Acinetobacter venetianus where, after $t=24 \mathrm{~h}$, production in the highest dilution of COREXIT rebounded to levels that exceeded the control (Fig. 3). However, in the case of Marinobacter hydrocarbonoclasticus, no such recovery occurred. In this respect, COREXIT may impart positive effects on hydrocarbon-degrading cultures capable of withstanding its initial toxicity. Because some Vibrio spp. are capable of metabolizing dispersant (Salter et al. 2009), it is reasonable to hypothesize that the increase in viability in cultures of Vibrio sp. in the live/dead staining analysis may be due to metabolism of COREXIT. However, even within this group, a reduction in heterotrophic secondary production was observed in the presence of COREXIT (Fig. 3), although the impact on Vibrio sp. was less significant than that on $M$. hydrocarbonoclasticus. The high turnover rates observed for numerous Vibrio spp. may likewise explain the reduced toxicity of COREXIT over other isolates.

\section{CONCLUSIONS}

Hydrocarbon degradation in the marine environment is dependent on the ability of microorganisms to utilize hydrocarbons for growth and metabolism. The results of the current study demonstrate that microbial populations are susceptible to toxicity from the use of COREXIT ${ }^{\circledR}$ EC9500A when applied at prescribed concentrations. While the short-term goals of dispersants 
may be achieved, this study provides evidence that COREXIT ${ }^{\circledR}$ EC9500A differentially impacts hydrocarbon-degrading microorganisms. Although toxicity testing with bacteria is only a minor component of the development of new dispersants, these experiments demonstrate the importance of understanding the impact of dispersants on microbial communities, as there is potential to diminish the capacity of the environment to mitigate spills.

Acknowledgements. We thank W. Wood (NRL) for acquiring the samples used in this study, P. Gillevet and M. Sikaroodi (George Mason University) for assistance with LH-PCR analysis, B. Ringeisen (NRL) for helpful discussions and support of this work, R. Jonas (George Mason University) for comments on the draft manuscript and L. Tender (NRL) for providing the dispersant used in these experiments. We acknowledge the Naval Research Laboratory base program for support of this project.

\section{LITERATURE CITED}

Aharon P, Fu B (2000) Microbial sulfate reduction rates and sulfur and oxygen isotope fractionations at oil and gas seeps in deepwater Gulf of Mexico. Geochim Cosmochim Acta 64:233-246

Aiyar SE, Gaal T, Gourse RL (2002) rRNA promoter activity in the fast-growing bacterium Vibrio natriegens. J Bacteriol 184:1349-1358

Atlas RM (1981) Microbial degradation of petroleum hydrocarbons-an environmental perspective. Microbiol Rev 45:180-209

Brakstad OG (2008) Natural and stimulated biodegradation of petroleum in cold marine environments. In: Margesin $\mathrm{R}$, Schinner F, Marx JC, Gerday C (eds) Psychrophiles: from biodiversity to biotechnology. Springer Verlag, Berlin, p 389-407

Coastal Response Research Center (2010) Deepwater Horizon dispersant use. Meeting Report. University of New Hampshire, Durham, NH

Couillard CM, Lee K, Legare B, King TL (2005) Effect of dispersant on the composition of the water-accommodated fraction of crude oil and its toxicity to larval marine fish. Environ Toxicol Chem 24:1496-1504

Garcia-Valdes E, Cozar E, Rotger R, Lalucat J, Ursing J (1988) New naphthalene-degrading marine Pseudomonas strains. Appl Environ Microbiol 54:2478-2485

Gauthier MJ, Lafay B, Christen R, Fernandez L, Acquaviva M, Bonin P, Bertrand JC (1992) Marinobacter hydrocarbonoclasticus gen. nov., sp. nov., a new, extremely halotolerant, hydrocarbon-degrading marine bacterium. Int $\mathrm{J}$ Syst Bacteriol 42:568-576

Hamdan LJ, Jonas RB (2006) Seasonal and interannual dynamics of free-living bacterioplankton and microbially labile organic carbon along the salinity gradient of the Potomac River. Estuar Coast 29:40-53

> Hamdan LJ, Gillevet PM, Sikaroodi M, Pohlman JW, Plummer RE, Coffin RB (2008) Geomicrobial characterization of gas hydrate-bearing sediments along the mid-Chilean margin. FEMS Microbiol Ecol 65:15-30

> Head IM, Jones DM, Roling WFM (2006) Marine microorganisms make a meal of oil. Nat Rev Microbiol 4:173-182

Hobbie JE, Daley RJ, Jasper S (1977) Use of Nuclepore filters for counting bacteria by fluorescence microscopy. Appl Environ Microbiol 33:1225-1228

Hollaway SL, Faw GM, Sizemore RK (1980) The bacterial community composition of an active oil field in the northwestern Gulf of Mexico. Mar Pollut Bull 11:153-156

Joye SB, Boetius A, Orcutt BN, Montoya JP, Schulz HN, Erickson MJ, Lugo SK (2004) The anaerobic oxidation of methane and sulfate reduction in sediments from Gulf of Mexico cold seeps. Chem Geol 205:219-238

Jung JH, Yim UH, Han GM, Shim WJ (2009) Biochemical changes in rockfish, Sebastes schlegeli, exposed to dispersed crude oil. Comp Biochem Physiol Part C: Toxicol Pharmacol 150:218-223

Labson VF, Clark RN, Swayze GA, Hoefen TM and others (2010) Estimated lower bound for leak rates from the Deepwater Horizon spill-Interim report to the Flow Rate Technical Group from the Mass Balance Team. U.S. Geological Survey Open-File Report 2010-1132

Lanoil BD, Sassen R, La Duc MT, Sweet ST, Nealson KH (2001) Bacteria and archaea physically associated with Gulf of Mexico gas hydrates. Appl Environ Microbiol 67: 5143-5153

Leahy JG, Colwell RR (1990) Microbial degradation of hydrocarbons in the environment. Microbiol Mol Biol Rev 54: 305-315

Lindstrom JE, Braddock JF (2002) Biodegradation of petroleum hydrocarbons at low temperature in the presence of the dispersant Corexit 9500. Mar Pollut Bull 44: 739-747

Litchfield CD, Sikaroodi M, Gillevet PM (2005) The microbial diversity of a solar saltern on San Francisco Bay. In: Gunde-Cimerman N, Oren A, Plemenitaš A (eds) Adaptation to life at high salt concentrations in Archaea, Bacteria, and Eukarya. Springer, Dordrecht, p 59-69

Lloyd KG, Albert DB, Biddle JF, Chanton JP, Pizarro O, Teske A (2010) Spatial structure and activity of sedimentary microbial communities underlying a Beggiatoa spp. mat in a Gulf of Mexico hydrocarbon seep. PLoS ONE 5(1):e8738

Mills HJ, Hodges C, Wilson K, MacDonald IR, Sobecky PA (2003) Microbial diversity in sediments associated with surface-breaching gas hydrate mounds in the Gulf of Mexico. FEMS Microbiol Ecol 46:39-52

National Research Council Committee on Oil in the Sea (2003) Oil in the sea III: inputs, fates and effects. National Academies Press, Washington, DC

Orcutt BN, Joye SB, Kleindienst S, Knittel K and others (2010) Impact of natural oil and higher hydrocarbons on microbial diversity, distribution, and activity in Gulf of Mexico cold-seep sediments. Deep-Sea Res II 57:2008-2021

Reed AJ, Lutz R, Vetriani C (2006) Vertical distribution and diversity of bacteria and archaea in sulfide and methanerich cold seep sediments located at the base of the Florida Escarpment. Extremophiles 10:199-211

> Richardson LL, Miller AW, Broderick E, Kaczmarsky L, Gantar M, Stanić D, Sekar R (2009) Sulfide, microcystin, and the etiology of black band disease. Dis Aquat Org 87: $79-90$

Salter I, Zubkov MV, Warwick PE, Burkill PH (2009) Marine bacterioplankton can increase evaporation and gas transfer by metabolizing insoluble surfactants from the air-seawater interface. FEMS Microbiol Lett 294:225-231

Smith DC, Azam F (1992) A simple, economical method for measuring bacterial protein synthesis rates in seawater using ${ }^{3} \mathrm{H}$-leucine. Mar Microb Food Webs 6:107-114

US EPA (U.S. Environmental Protection Agency) (1995) COREXIT ${ }^{\circledR}$ EC9500A NCP Product schedule. http://www. epa.gov/osweroe1/content/ncp/products/corex950.htm 
US EPA (2010a) Comparative toxicity of eight oil dispersant products on two Gulf of Mexico aquatic test species. http:// www.epa.gov/bpspill/reports/phase2dispersant-toxtest.pdf

US EPA (2010b) National Contingency Plan product schedule. http://www.epa.gov/emergencies/content/ncp/product_schedule.htm

Vaneechoutte M, Nemec A, Musilek M, van der Reijden TJK and others (2009) Description of Acinetobacter venetianus ex Di Cello et al. 1997 sp. nov. Int J Syst

Editorial responsibility: Antje Boetius,

Bremen, Germany
Evol Microbiol 59:1376-1381

Venkateswaran K, Iwabuchi T, Matsui Y, Toki H, Hamada E, Tanaka H (1991) Distribution and biodegradation potential of oil-degrading bacteria in North Eastern Japanese coastal waters. FEMS Microbiol Lett 86:113-121

Zahed MA, Aziz H, Isa M, Mohajeri L (2010) Effect of initial oil concentration and dispersant on crude oil biodegradation in contaminated seawater. Bull Environ Contam Toxicol 84:438-442

Submitted: August 25, 2010; Accepted: December 9, 2010 Proofs received from author(s): February 18, 2011 